\title{
Extrahepatic Bile Duct Adenocarcinoma, Intestinal Type
}

National Cancer Institute

\section{Source}

National Cancer Institute. Extrahepatic Bile Duct Adenocarcinoma, Intestinal Type. NCI

Thesaurus. Code C96938.

An adenocarcinoma that arises from the extrahepatic bile ducts. It is characterized by the presence of neoplastic tubular glands lined by columnar cells or neoplastic glands lined by goblet cells. 